\title{
GálnÉ, HORVÁth ILDIKó-KeCZER, GABRIELLA: Society-forming Effects of the System of Schools for Children Living on Detached Farms
}

\begin{abstract}
Summary
During the last one and a half century schools in the outskirts played an important role in elimination of illiteracy, and in shaping the traditional life in detached farms. At the time of their construction they were regarded as revolutionary ones while by today they have been surpassed.

\section{Introduction}

When we are examining the present we are exploring the past so aiming at the future. From the beginning, in these 150 years small schools in the outskirts of Hódmezóvásárhely made huge efforts to the cultural development of the world of scattered farms. In the last fifty years this special world lost its population and consequently the schools ceased to exist, too. These institutions worked with a small number of pupils, they have become too expensive to maintain so their maintenance is not reasonable in their present form, what is more even their efficiency is questionable today. Teachers working there deserve respect since they did an enormous job but unfortunately, there is no need either for their job or these small schools regarding today's requirements.
\end{abstract}

\section{Material and Method}

We are trying to find the answer for the following question: Are a traditional form of settlement and its schooling system, which was considered as a modern one at the time, able to perform their duties even today? At present it is one of the most significant challenges to ensure equal opportunity which means a new task even for teachers. It is important to get profound knowledge about the past of this schooling system and about the related social class on the bases of primary and secondary researches.

\section{Small schools in the outskirts are telling stories about a surpassed way of living}

„We love the boundless space around the town, the cows pasturing along the farm tracks, the furrows in the fields and the scattered farms which are telling stories about a surpassed world. About a way of living which characterized the local life for centuries." (A contributor to „Délvilág”, 2001).

Let's go back in time and examine how the number of farm schools changed during the decades. In 1857 Hódmezỏvásárhely was the fifth town of the country. At that time there was only one school in the outskirts, while from 1860 a rapid progress took its beginning. In 1890 we can find 25 in the outskirts under the rule of the Church. The number of school-age children came close to $4.000,2.000$ of which registered at different farm schools, 1.000 of which frequently went to school; the others had to work at home so they did not attend school at times.

In 1938 there were 43 state schools for children living in farms, with 2.432 registered 
pupils. $39 \%$ of the population lived in isolated farms, $41 \%$ of the total school-age children went to a farm school. Once these schools used to mushroom around the town for $5 \mathrm{kms}$ round (map) (Körtvélyessy, 1985).

It was not rare to have a class with 50-100 children. In 1875 in the farm school of Szörhát 54 pupils wrote kneeling on the ground in a room of $18 \mathrm{~m}^{2}$. At the same time the utilization of classrooms was asymmetrical. According to a contemporary report there were $30-33$ children in a classroom in the town while 14 in the farm school.

Teachers of these outskirt schools - from dualism up today - played an important role to eliminate illiteracy and then to rise the life-style and cultural level of people who lived in farms. Data of Table1 show their result:

Table 1. Percentage of the illiterate in the average of children above 6

\begin{tabular}{|l|l|}
\hline \multicolumn{1}{|c|}{$\mathbf{E} \mathbf{v}$} & $\%$ \\
\hline 1870 & 68 \\
\hline 1880 & 56 \\
\hline 1890 & 46,7 \\
\hline 1900 & 38,6 \\
\hline 1920 & 31,3 \\
\hline 1930 & 18 \\
\hline 1940 & 5,1 \\
\hline
\end{tabular}

Source: Beszámoló a város lakosságának oktatási, kulturális ellátásáról a VII. ötéves terv fejlesztési koncepció meghatározására (1985)

It is sad to consider these data even if the results here are better than the country average by some percentages.

The schools were built in different styles. We can find historic descriptions about small schools in remote places with classical brick buildings (eg. Mátyáshalom, Sóshalom etc.).

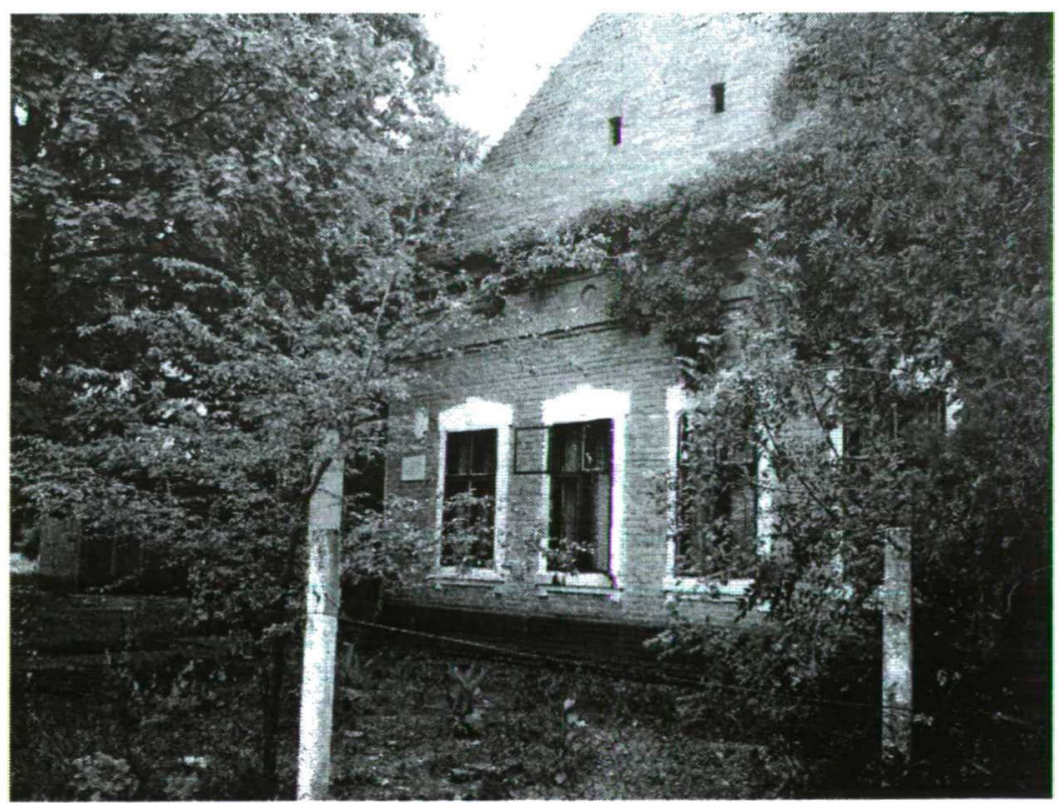

Picture 1. School in Mátyáshalom

(Source: photo taken by the author) 
The School of Mátyáshalom has been declared a historic monument by the local authority, there is a „reading circle” in the school of Sóshalom. Buildings from the period of Klébersberg Kunó have a typical feature, eg: schools in Szentkirály, Vajhát, Batida.

We can find buildings which originally were not built as schools, eg: the school of Dózsa TSZ.

There was a difference between the original small schools and the schools with fused farm-connections. We can find schools with one teacher, and with 1-8 class together (Atkasziget, Alsókopáncs, Répáshát); schools where 1-4 and 5-8 classes were fused (Kishomok, Dózsa TSZ); or schools where pupils learned in partly fused groups (Sóshalom, Szentkirály, Batida, Erzsébet); and finally not fused schools (Szikáncs).

There were schools where teaching was only in the morning, while in other schools teaching was in the morning or in the afternoon in in a weekly rotation. According to the system, one or two teachers (often a couple) taught in one school (eg. Atkasziget, Répáshát), or 4-5 teachers who partly lived locally or commuted from the town (eg Sóshalom, Szentkirály). In the farm centre of Szikáncs there was a period when even a school orchestra played music. And finally, there was a school where only one teacher taught 50-70 pupils. But this belongs to the past.

It was typical that couples lived locally, or other teachers went to school - from the town - by bicycle, by motorbike - following the technological development.

In the 60s only 1-2 teachers had a car. The buses went only once a day. In winter when the roads were impassable they walked to school.

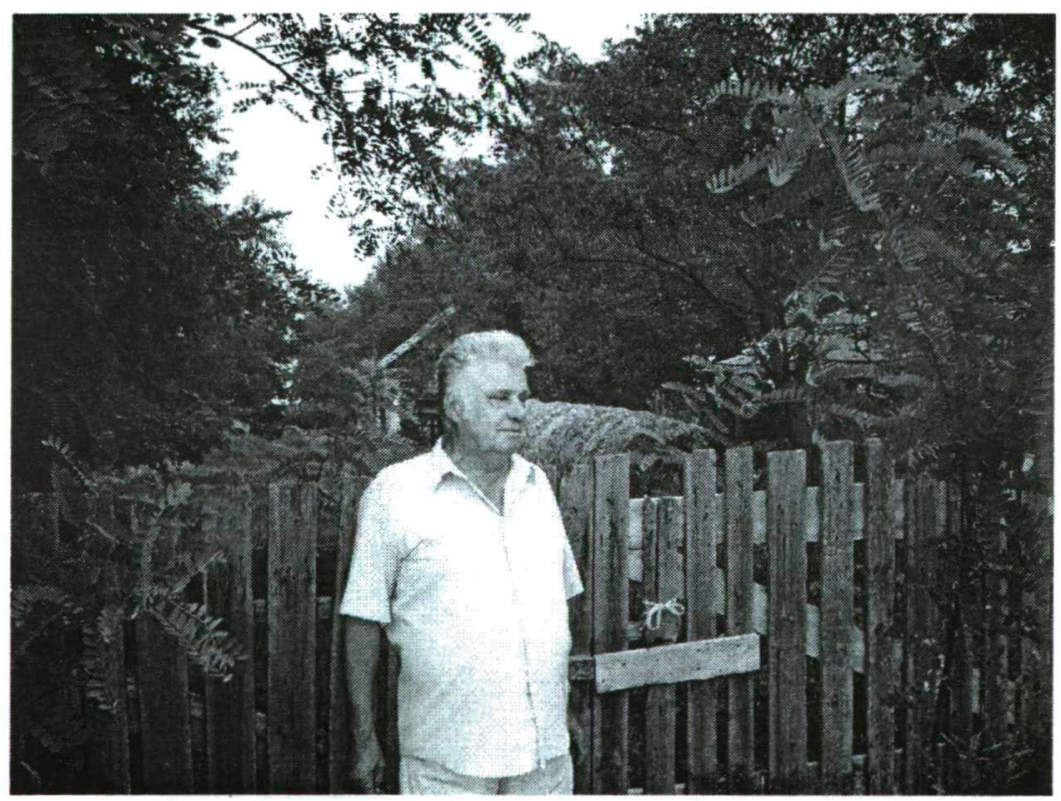

Picture 2. Teacher lived in the farm school among people

(Source: photo taken by the author)

Every day pupils went to school from the distance of 2,5-3 km, from every direction. Everybody had a wooden knife they cleaned their boots from the mud with, then they washed them at the school well and then they were allowed to enter the school.

In winter they often had so-called „coal-breaks”. Every pupil took the „kindling” to help heating in the school. 
More than a third of children living in detached farms went to primary school in places where there were no paved roads.

In these pupil groups independent and direct ways of teaching/learning followed each other in rotation. In a lesson of 45 minutes teachers had to give tasks for indipendent classes, ensuring the success of independent learning, in the meantime pupils in the direct class solved lead-in tasks, then teachers started the direct activities. At the end of the lesson they were given some more independent tasks while the teacher checked the work and evaluated the work of the independent class. It required great preparation, organization and planning from the teacher. The independent classes could hear the direct activities, so they could meet more than once with the given material. Sometimes the elder pupils helped the younger ones. In the morning the younger said the multiplication table aloud in choir under the guidance of an upper-grader.

Schoolbooks did not change for decades so the ,stative environment" was typical of the school work, which differs from today's practice- sometimes books are changed without a strong reason. What the teacher said was intangible; what he/she suggested the parents and the pupils strived to fulfill. The teachers there took care of the talented pupils, as well, so they became teachers, kindergarten-teachers, agricultural engineers and mechanics. Many of them chose a trade to learn, while others stayed at the ,handle of plough".

From the 60s with diffusion of large-scale farming, isolated farms were brought to an end, and farm schools began to become empty. People lived in boondocks were moved into closed settlements that times fashioned, new built block of flats (Zsótér, 2008). In some places the upper primary part was ceased, the pupils were taken to primary school hostels.

In the $60 \mathrm{~s}$ farm schools belonged to the outskirts directorate. From time to time the headmaster took a visit with the carriage of the town; the school inspector visited the school in every 2-3 year. Instead of constant checking trust and efficiency were the most important factors.

There were strong and profound ties between people in the farms and the teacher in the farm school who taught locally even for 20-30 years. Finally, beside depopulation, one of the reasons for closing down a school was that the teacher there retired.

There was no real opportunity to give homework or to learn at home. As soon as the children got home, they had to start work around the farm. They took themselves to the adulthood the knowledge they got from school. Teachers kept strict discipline, it was half of the success. If the teacher condemned the pupil and he/she complained at home, he/she got the sentence from the parents, too. Parents did not let children bring shame on them. Authoritarianism was typical. This way the children from farms knew less but it was strictly demanded from them by their teacher.

In the last decade the number of pupils decreased drastically in the farm schools even in the farm centres (Table 2).

Table 2. Number of pupils In farm schools and in farm centres in the school year 1995/1996

\begin{tabular}{|l|c|}
\hline Farm centre, farm school & Number of puplis (person) \\
\hline Batida & 7 \\
\hline Erzsébet & 47 \\
\hline Kútvölgy & 9 \\
\hline Szikáncs & 68 \\
\hline Mátyáshalom & 10 \\
\hline
\end{tabular}

Source: Hódmezővásárhely Megyei Jogú Város jelentése az önkormányzatnak az 1995. évrõl (1996) 
To examine the data of the table it is worth mentioning that in the given school year the total number of pupils was 4.840 in Hódmezővásárhely, 138 of which were pupils in the outskirts.

By today the maintenance of these schools has become uneconomical, so in 2008 the local government closed down all the farm schools. Pupils are taken to the town school with a well-organized school bus accompanied by a teacher. With this decision the local authority aimed to decrease their disadvantages.

\section{Summary}

In the last fifty years the world of detached farms changed a lot. It had to face with the new challenges. After the farm schools had fulfilled their historic duty they became deserted and then ceased to exist.

From the illiteracy of the 1870 s the population of the outskirts took a huge step ahead. Today children from detached farms learn foreign languages, IT within the frames of classified, divided education. It is a great help from the local government to ensure the school bus but the disadvantageous situation of the commuting children could not be ceased even with the greatest support. At the same time this disadvantage can be reduced, it ensures the opportunity of further education.

Traditions of the past make the development unique in the Great Plain the condition of which is to build in the experiences of past into the present with emphatic hands. This is what makes evolution smooth, preventing both uniform and stereotyped development (Letricht, 1980).

\section{Bibliography}

Délvilág Hódmezövásárhelyi munkatársa (2009): $10+1$ dolog, amit szeretünk Vásárhelyen, 4. pont; 2009. május 2.

Körtvélyessy L. (1985): Hódmezővásárhely gazdasági földrajza a századfordulón. Vásárhelyi tanulmányok, 10 . kötet.

Sz. n. (1985): Városi T. V. B. Müvelödési Osztály Vezetőjének 1985-ben készültt Beszámoló a város lakosságának oktatási, kulturális ellátásáról a VII. ötéves terv fejlesztési koncepció meghatározására.

Sz. n. (1996): Hódmezővásárhely Megyei Jogú Város jelentése az önkormányzatnak az 1995. évröl. Kézirat, P.106.

Letrik E. (1980): Utószó, in:A. N. J. Den Hollander: Az Alföld települései és lakói, Mezőgazdasági Kiadó.

Zsótér B. (2008): Lakáshelyzet vizsgálat egy délkelet-alföldi településen. Az önkormányzásra való átállást követö időszakban (1990-2006). Comitotus, XVII/9-10., 175. szám, pp. 64-72. 